\title{
Morphological and physiological responses of the potato stem transport tissues to dehydration stress
}

\author{
Ernest B. Aliche ${ }^{1,2} \cdot$ Alena Prusova-Bourke $^{3} \cdot$ Mariam Ruiz-Sanchez $^{1} \cdot$ Marian Oortwijn $^{1} \cdot$ Edo Gerkema $^{3}$. \\ Henk Van $\mathrm{As}^{3} \cdot$ Richard G. F. Visser ${ }^{1} \cdot$ C. Gerard van der Linden ${ }^{1}$
}

Received: 26 August 2019 / Accepted: 24 December 2019 / Published online: 8 January 2020

(c) The Author(s) 2020

\begin{abstract}
Main conclusion Adaptation of the xylem under dehydration to smaller sized vessels and the increase in xylem density per stem area facilitate water transport during water-limiting conditions, and this has implications for assimilate transport during drought.
\end{abstract}

\begin{abstract}
The potato stem is the communication and transport channel between the assimilate-exporting source leaves and the terminal sink tissues of the plant. During environmental stress conditions like water scarcity, which adversely affect the performance (canopy growth and tuber yield) of the potato plant, the response of stem tissues is essential, however, still understudied. In this study, we investigated the response of the stem tissues of cultivated potato grown in the greenhouse to dehydration using a multidisciplinary approach including physiological, biochemical, morphological, microscopic, and magnetic resonance imaging techniques. We observed the most significant effects of water limitation in the lower stem regions of plants. The light microscopy analysis of the potato stem sections revealed that plants exposed to this particular dehydration stress have higher total xylem density per unit area than control plants. This increase in the total xylem density was accompanied by an increase in the number of narrow-diameter xylem vessels and a decrease in the number of large-diameter xylem vessels. Our MRI approach revealed a diurnal rhythm of xylem flux between day and night, with a reduction in xylem flux that is linked to dehydration sensitivity. We also observed that sink strength was the main driver of assimilate transport through the stem in our data set. These findings may present potential breeding targets for drought tolerance in potato.
\end{abstract}

Keywords Drought $\cdot$ Potato $\cdot$ Xylem $\cdot$ MRI $\cdot$ Sugar transport $\cdot$ Phloem

Communicated by Anastasios Melis.

Electronic supplementary material The online version of this article (https://doi.org/10.1007/s00425-019-03336-7) contains supplementary material, which is available to authorized users.

C. Gerard van der Linden

gerard.vanderlinden@wur.nl

1 Plant Breeding, Wageningen University and Research, Droevendaalsesteeg 1, 6708 PB Wageningen, The Netherlands

2 Graduate School Experimental Plant Sciences, Droevendaalsesteeg 1, 6708 PB Wageningen, The Netherlands

3 Laboratory of Biophysics, Wageningen University and Research, Stippeneng 4, 6708 WE Wageningen, The Netherlands

\section{Introduction}

Potato (Solanum tuberosum L.) is the world's third most important food crop (Bradshaw 2010) with a total global cultivation land area of about 20 million hectares (Haverkort et al. 2013). However, potato plant is also drought sensitive (Obidiegwu et al. 2015). Hijmans (2003) estimated that drought will reduce potato yield by up to $32 \%$ globally between the years 2040-2069. Drought is gaining global concern in view of climate change scenarios and its huge negative impacts on agriculture resulting from reduced rainfall and increased evaporation (Grayson 2013). Therefore, research efforts toward improving potato tuber yield under drought are increasing.

The role of the potato stem in drought tolerance has hardly been studied, even though the stem plays vital and indispensable roles in the bidirectional transport of water, 
photo-assimilates, and other products of metabolism, with the vascular tissues of the stem, xylem, and phloem, mediating the transport processes (Gartner 1995). The stem is also a potential reserve water pool to maintain leaf water potential in functional boundaries (Banik et al. 2016; Lechthaler et al. 2016). The stem xylem which consists of tracheids (narrow tubes with tapered ends) and vessel members that make up the vessel (wider tubes but shorter than tracheids and joined end-to-end), transports water and nutrients from the soil to different plant parts. Xylem transport is driven by transpiration and, therefore, operates under negative pressure, and it involves various stem components (Holbrook and Zwieniecki 2011; Tyree and Zimmermann 2013).

The phloem transports photo-assimilates from source tissues to sink organs of the plant for growth, respiration, and/ or storage (Ryan and Asao 2014). It has highly specialized living cells called sieve elements (SEs) that are connected to the phloem companion cells (CC) forming the SE-CC complexes (Jensen et al. 2012). Phloem transport has been described as mass flow of assimilates driven by hydrostatic pressure (Knoblauch and Peters 2010; Sellier and Mammeri 2019). This mass flow is facilitated by an osmotic pressure gradient between source and sink tissues of the plant as proposed by Munch (1930) and widely accepted for herbaceous plants like potato despite divergent viewpoints (De Schepper et al. 2013; Johnson et al. 1992).

Hydrodynamic interactions between the xylem and phloem have been demonstrated in different plant systems (Sevanto et al. 2011; Zwieniecki et al. 2004; Zimmermann et al. 2013). These interactions become crucial under suboptimal conditions like drought as the xylem is prone to cavitation (Pockman and Sperry 2000). Cavitation is the formation of air bubbles in the xylem water column in the regions of lower pressure (Vilagrosa et al. 2012). Cavitation breaks the water columns along the transpiration stream and impairs the hydraulic conductance of xylem vessels leading to a reduction in xylem flux (Cochard and Tyree 1990; Torres-Ruiz et al. 2011; Köcher et al. 2009). The phloem is also vulnerable to water limitation stress (Sheikholeslam and Currier 1977), mainly due to loss of turgor pressure (van Bel 2003b). However, an enhanced sucrose retrieval from lateral sinks into the sieve tube during drought can generate a negative water potential in the SEs, thereby attracting water from the neighbouring xylem to drive transport (De Schepper et al. 2013; Van Bel 2003a). Therefore, xylem-phloem interactions can alleviate the effects of drought on these stem vascular tissues (Lampinen and Noponen 2003; Cernusak et al. 2003). However, under severe drought conditions, transport failure may not be prevented (Sevanto 2014). In potato plant, an optimal xylem-phloem transport interaction is critical considering the competition for photoassimilates between the above-ground and underground tissues (Kooman and Rabbinge 1996). Interestingly, a high phloem flux-to-xylem flux ratio in Solanaceae at night has been reported (Windt et al. 2006). This ratio is a measure of the fraction of xylem water that is used for phloem transport. In fact, diurnal rhythms have been shown to occur in xylem-phloem transport interactions in potato plant (Baker and Moorby 1969; Prusova 2016). However, research efforts towards understanding the interactions of these vascular tissue components under drought conditions in potato plants are limited.

In the present study, we examined the dehydration responses of different regions of the potato stem in terms of their vascular tissue morphology and sap transport, and how dehydration stress affects the interaction between xylem transport and phloem transport. As these interactions are likely to be under circadian control, we included both daytime and night-time measurements of xylem and phloem behaviour. The effect of dehydration on xylem morphology and flow, stomatal conductance, and phloem transport was evaluated both under stress and control conditions. Our results indicate that morphological changes in xylem diameter and density under drought may be associated with xylem flux and dehydration tolerance in potato plants.

\section{Materials and methods}

\section{Plant materials, growth, and phenotyping}

Four potato cultivars (Biogold, Festien, Hansa, and Mondial) were grown from seed tubers in the greenhouse at Unifarm, Wageningen University and Research, The Netherlands. The cultivars were selected based on their dehydration responses in previous greenhouse pot trials in which Biogold and Mondial showed the highest and lowest levels of stress resilience, respectively, in terms of tuberization potential and final tuber yield (Aliche et al. 2020). Pre-sprouted seed tubers of the four cultivars were planted in $19 \mathrm{~cm}$-diameter pots in October 2015 under greenhouse conditions of 16/8 h day/ night periods and $22.5 / 18.0{ }^{\circ} \mathrm{C}$ day/night temperatures. A staggered planting approach was adopted allowing 1 week in between planting slots starting with the later maturing cultivars before planting the early maturing cultivars to synchronize stress application with plant phenology as much as possible. Thus, the planting sequence was as follows: first, Festien, then Mondial/Hansa, and lastly, Biogold. Dehydration was applied to three replicates of each cultivar after 1 week from the emergence of the last planted (early maturing) cultivar, which was 2 and 3 weeks from the emergence of the later maturing cultivars, respectively. Thus, the dehydration treatment was applied to coincide with stolon initiation stage of development. The dehydration-treated plants were given $75 \mathrm{ml}$ of water only when the soil water content dropped below $15 \% \mathrm{v} / \mathrm{v}$ (that is, volume of water per volume 
of soil) as measured with a Grodan Water Content Meter (Grodan, Roermond, The Netherlands). The control plants received $>200 \mathrm{ml}$ per day depending on the water amount used by the plant. Soil water reduction was also monitored using Parrot Flower Power ${ }^{\circledR}$ sensors. After 21 days of dehydration treatment, stomatal conductance was measured using a Decagon SC-1 Leaf Porometer. Measurements were taken from source and sink leaves at 09:30-11:00 $\mathrm{h}$ (day time) and 19:00-21:00 h (night time) given the following lighting regime: 02:00-08:00-18:00 for artificial lighting-dawn-dusk, respectively. Source leaf is defined as the 5-6th fully expanded leaf from the plant apex, while sink leaf (young leaf that produces less assimilates than it requires) is the third leaf from the plant apex. The day length $(16 \mathrm{~h})$ period was maintained in the greenhouse compartment using artificial PAR (photosynthetic active radiation) lighting $\left(\sim 150 \mu \mathrm{mol} \mathrm{m}^{-2} \mathrm{~s}^{-1}\right.$ light intensity) when there was no natural day light. Plant tissues were sampled after 28 days of dehydration (DOD), during the day and also at night, for biochemical analysis. Plant biomass was determined by weighing the various tissues of the plant including tubers, roots, source, and sink leaves. The dehydration lasted for 7 weeks and a recovery treatment was given for 4 weeks. Tuber/shoot weight ratio was computed by dividing tuber biomass by shoot biomass at 28 DOD and 77 DOD to evaluate the carbon partitioning rate across two time points in the study. Plant height was scored at three time points in the growing season: before dehydration application (H0), after 7 weeks of dehydration (H1) and after 4 weeks of recovery treatment $(\mathrm{H} 2)$. Increase in plant height during stress $(\Delta \mathrm{H}-$ $\mathrm{Str} .=\mathrm{H} 1-\mathrm{H} 0)$ and that during recovery $(\Delta \mathrm{H}-\mathrm{Rec} .=\mathrm{H} 2$ $-\mathrm{H} 1)$ were determined.

\section{Stem cross-sectional analysis}

During tissue sampling, the lower and upper regions of the stem were sampled with sharp blades for cross-sectional analysis. Lower stem tissue was sampled at $\sim 10 \mathrm{~cm}$ above the soil surface, below the lowest leaf. The upper stem was sampled just below the sink leaves, that is, below the third open young leaf. The cut stem pieces, about $0.5 \mathrm{~cm}$ in length, were immersed in $1 \mathrm{ml}$ of fixation buffer (5\% glutaraldehyde and $0.1 \mathrm{M}$ phosphate buffer) in Eppendorf tubes and stored overnight in the dark at $4{ }^{\circ} \mathrm{C}$. Permeation of the fixation buffer into the tissues was ensured with a vacuum pump (Membran Vakuumpumpe Vacuubrand GMBH + CO). Samples were washed four times for $15 \mathrm{~min}$ in $0.1 \mathrm{mM}$ phosphate buffer, followed by four 15-min washes in deionized water. Finally, the stem samples were dehydrated by washing in the following concentrations of ethanol: $10 \%, 30 \%$, $50 \%, 70 \%, 96 \%$, and $100 \%$. Each wash lasted $1 \mathrm{~h}$ except the $70 \%$ wash, which was only for $15 \mathrm{~min}$. The washed samples were infiltrated with activated Kulzer Technovit 7100 (0.1 M phosphate buffer, 0.1 M KH2PO4, and 0.1 M Na2HPO4, $100 \mathrm{ml}$ ). Each sample was embedded in $15 \mathrm{ml}$ Technovit 7100 mixed with $1 \mathrm{ml}$ Hardener II. The setup was dried overnight to harden. The embedded stem was sectioned on a microtom (Reichert-Jung Leica Rijswijk, Netherlands 2055) and the cut transverse sections were placed on slides and stained with Toluidine-Blue. The slides were dried on Slide Warmer SW85 (VWR ${ }^{\mathrm{TM}}$ Avantor). After slide preparation, the sections were visualized under the light microscope [Carl Zeiss D-7082 Oberkochen (Axiophot)]. Section images were captured by a Nikon camera mounted on the microscope, and analysed with the ImageJ2 software package (Rueden et al. 2017). The xylem vessels were characterized into size classes based on their diameter and quantified. The size classes are: 0-20 $\mu \mathrm{m}, 20-40 \mu \mathrm{m}, 40-60 \mu \mathrm{m}, 60-80 \mu \mathrm{m}$, and $>80 \mu \mathrm{m}$. Number of vessels per size class, surface area of vessels, and xylem density per stem area were scored. Based on these measurements, the mean total xylem surface area and xylem density per unit area were calculated per the entire stem cross section.

\section{Sap extraction and biochemical analysis}

Stem tissues of 2-3 cm length were collected from upper and lower regions of the stem (see above). Sap was extracted from the sampled stem tissues using a centrifugation method (Hijaz and Killiny 2014). Each tissue was quickly inserted in a spin column fitted in an Eppendorf tube and placed in IEC Micromax Eppendorf Centrifuge 5417C. After $8 \mathrm{~min}$ of centrifugation at $13,000 \mathrm{rpm}$, the sap collected in the Eppendorf tubes was stored at $-80{ }^{\circ} \mathrm{C}$, likewise the stem tissues from which sap was collected, for biochemical analyses (Hijaz and Killiny 2014). The sugar content of the sap and stem tissues was determined using a Boehringer Mannheim Sucrose/D-Glucose/D-Fructose kit (Kinkade 1987). Each $1 \mu \mathrm{l}$ of sap was hydrolysed to completion with $1 \mathrm{U}$ $\beta$-fructosidase (Karley et al. 2002). The following sugars were quantified: sucrose, glucose, and fructose.

\section{Magnetic resonance imaging (MRI)}

Xylem and phloem flow in the lower stem region of 8-10-week-old potato plants were measured using a plantdedicated MRI scanner (Windt et al. 2006) consisting of a vertically orientated superconducting magnet with a $50 \mathrm{~cm}$ vertical free bore (Magnex, Oxford, UK). For induction and detection of the flow signal, an openable RF coil of $4 \mathrm{~cm}$ diameter was used inside a $1 \mathrm{~T} / \mathrm{m}$ gradient set that allowed to insert intact plants (Bruker, Karlsruhe, Germany) and controlled by the Avance console (Bruker, Karlsruhe, Germany) (Homan et al. 2007). Here, we used a pulsed field gradient turbo spin echo (PFG-TSE) sequence for measurement of xylem sap displacement (Scheenen et al. 2000). For every 
pixel within an image, we obtained a propagator (a displacement spectrum) (Scheenen et al. 2000). This propagator was analysed by discriminating non-flowing tissue water and flowing water in xylem and phloem with an approach described elsewhere (Scheenen et al. 2000; Van As 2006; Windt et al. 2006). Briefly, the propagator shows the probability of having a spin at its initial position displaced by a distance, $R$, in a given time interval, $\Delta$. Non-flowing water only shows diffusional behaviour, resulting in a symmetric displacement probability around the initial position (displacement 0 ), whereas flowing water results in a displacement in one direction from the initial position. This different displacement behaviour was used to subtract the non-flowing water from the total propagator, resulting in the displacement probability of flowing water. For flowing water, the displacement axis $(R)$ was divided by the time $(\Delta)$ to obtain the flow profiles. This resulted in the following parameters for each pixel: volume flow, amount of non-flowing (stationary) water, flow conducting area (FCA), and average flow velocity. Flow measurements were carried out using the following imaging parameters: spectral width $=50 \mathrm{kHz}$, imaging matrix $=128 \times 128$ pixels, field of view $=17 \times 17 \mathrm{~mm}$, slice thickness $=3 \mathrm{~mm}$, echo time $=5 \mathrm{~ms}$. For the xylem measurements, the specific parameters were: turbo factor: 8 , number of averages: 2 , repetition time: $2500 \mathrm{~ms}$, displacement labelling time: $20 \mathrm{~ms}$, gradient duration: $4 \mathrm{~ms}, 32$ gradient steps, maximum gradient strengths: $400 \mathrm{mT} \mathrm{m}^{-1}$, and acquisition time: $42 \mathrm{~min}$. For the phloem measurements, the parameters were: turbo factor: 8 , averages: 4 , repetition time: $2000 \mathrm{~ms}$, labelling time: $150 \mathrm{~ms}$, gradient duration: $3 \mathrm{~ms}, 32$ gradient steps, maximum gradient strengths: $200 \mathrm{mT} \mathrm{m}^{-1}$, and acquisition time: 68 min (Prusova 2016). Data analysis was performed with IDL (ITT Visual Information Solutions, Boulder, Colorado, USA) using in-house processing, fitting, and quantification routines.

For the MRI measurements, greenhouse potato plants grown under dehydration and control conditions as described above until about $50 \mathrm{~cm}$ height were used. The plants were in their tuberization stage of development. The inner walls of the $19 \mathrm{~cm}$ pots were fitted with tubes that we used later on during the MRI measurements to cool the soil at night times. Prior to measurement, the stem was cleaned from old (lower) leaves (about $30 \mathrm{~cm}$ ) to be able to place the rf coil and gradient system around the stem. The plants were mounted (one plant per measurement including two replicates per treatment per cultivar) in the MRI machine for scanning of the lower stem region a day prior to the measurement to acclimatise. During the measurements, the soil was cooled to about $18-19^{\circ} \mathrm{C}$ at night by running cold water via the pot tubing. The dehydration stress inside the MRI scanner was four times milder in comparison to the greenhouse experiments of this paper due to technical limitations of the MRI machine, which requires more volume to detect its signals. That is, the stressed plants were watered with $100 \mathrm{ml} / 24 \mathrm{~h}$ and control plants received $100 \mathrm{ml} / 6 \mathrm{~h}$. The other day/night environmental conditions like temperature $\left(22.5 / 18^{\circ} \mathrm{C}\right)$, vapour pressure deficit $(1.7 / 1.2 \mathrm{KPa})$, and light intensity $\left(150 \mu \mathrm{mol} \mathrm{m}{ }^{-2} \mathrm{~s}^{-1} /\right.$ darkness $)$ were set to mimic the greenhouse conditions.

\section{Results}

\section{Plant height adaptation and biomass ratio}

The effect of plant height (size) on transport within the plant has been a subject of debate between scholars who support (Koch et al. 2004) or deny (West et al. 1999) any effects. Therefore, we investigated the increase in plant height of the four cultivars in this study during drought stress and after a recovery treatment. The 7 -week period of stress coincided with the exponential growth phase of the plants, whereas during the recovery treatment, the plants had passed the exponential growth phase. A comparison of the height increase between stressed and control plants during the 7 weeks of stress, $(\Delta \mathrm{H}-\mathrm{Str}$.), shows that growth rate was reduced under stress (Fig. 1a, Supplementary Figs. 1, 2). This was significant in Biogold and Hansa but not in the other two varieties. However, the height increase between stressed and control plants during recovery period, $(\Delta \mathrm{H}-$. Rec), showed no significant differences between both recovered and control plants (Fig. 1a). Additionally, tuber/shoot weight ratio at two time points, 28 and 77 days of drought (28DOD and 77DOD), varied among the cultivars suggesting differences in assimilate partitioning to tubers with time (Fig. 1b). Remarkably, Biogold showed no difference in tuber/shoot ratio between the two time points, while Festien apportioned more assimilates to tuber bulking than other cultivars at the end of the growing season, indicating the advantage of late maturity toward tuber yield. However, Festien was not as tolerant as Biogold given that its tuber/shoot ratio, following a pairwise comparison, was significantly reduced under dehydration at 77DOD relative to control condition at this time point (Festien: 77DOC $-77 \mathrm{DOD}=3.67$, p. $a d j=0.02$ versus Biogold: $77 \mathrm{DOC}-77 \mathrm{DOD}=1.91$, p.adj=0.76). Mondial and Hansa were least performers in tuber bulking at the two time points.

\section{Stomatal conductance}

During water shortage one of the mechanisms plants use to manage water loss is stomatal closure (Osakabe et al. 2014). Therefore, stomatal conductance was measured in both source and sink leaves during the day (09:30-11:00 h) and at night (19:00-21:00 h) in the greenhouse. The genotypes reduced stomatal conductance under dehydration 
(a)

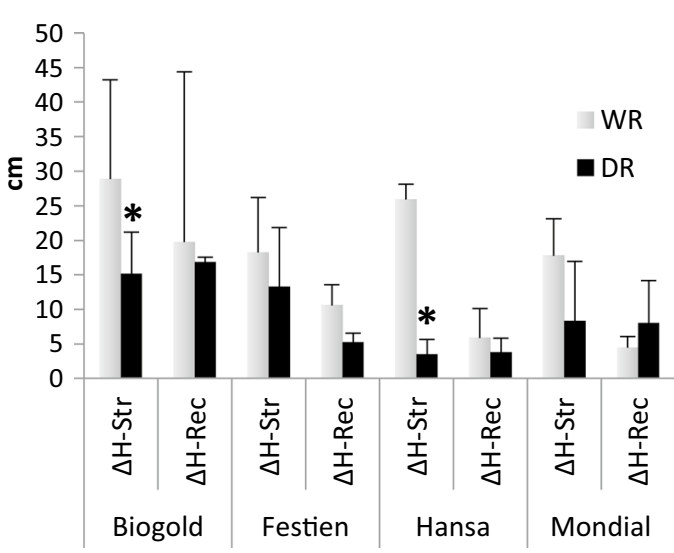

Fig. 1 a Graph showing the increase in plant height after 7 weeks of dehydration stress $(\Delta \mathrm{H}$-Str.) and after 4 weeks of recovery treatment $(\Delta \mathrm{H}-\mathrm{Rec})$. The stress and recovery scores were compared with their respective control conditions. Error bars are standard deviations between three biological replicates. $*=$ sig. $(p \leq 0.05)$, b tuber/shoot weight ratio of potato cultivars at two time points -28 and 77 days

especially in day time, with conductance levels showing a lower trend in the source leaves than in the sink leaves (Fig. 2). There was no significant stress effect on stomatal conductance at night, because conductance was generally low at night. Under normal conditions, the stomatal conductance was significantly reduced at night relative to day in the sink leaves. Biogold and Mondial retained a (b)

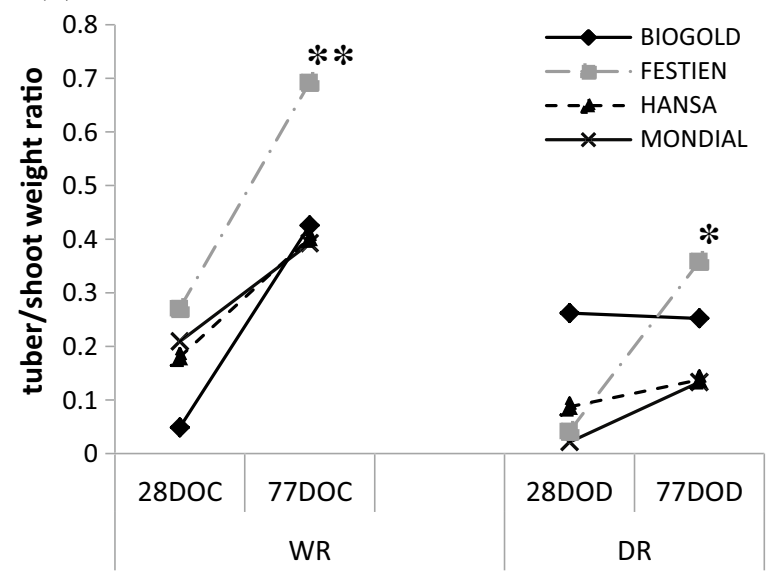

of drought stress (DOD) as compared to their control (WR) conditions that were not stressed (DOC: days of control). Three biological replicates per cultivar per treatment were sampled. ** indicates significant difference between stress and control treatments at the given time point

moderately low level of conductance under stress in their sink leaves during both day and night (Fig. 2), and from experiments of previous years had shown interesting contrasts in their dehydration response (Aliche et al., 2020). Therefore, we further investigated xylem flow, vessel structure, and sugar transport in the stem of Biogold and Mondial.

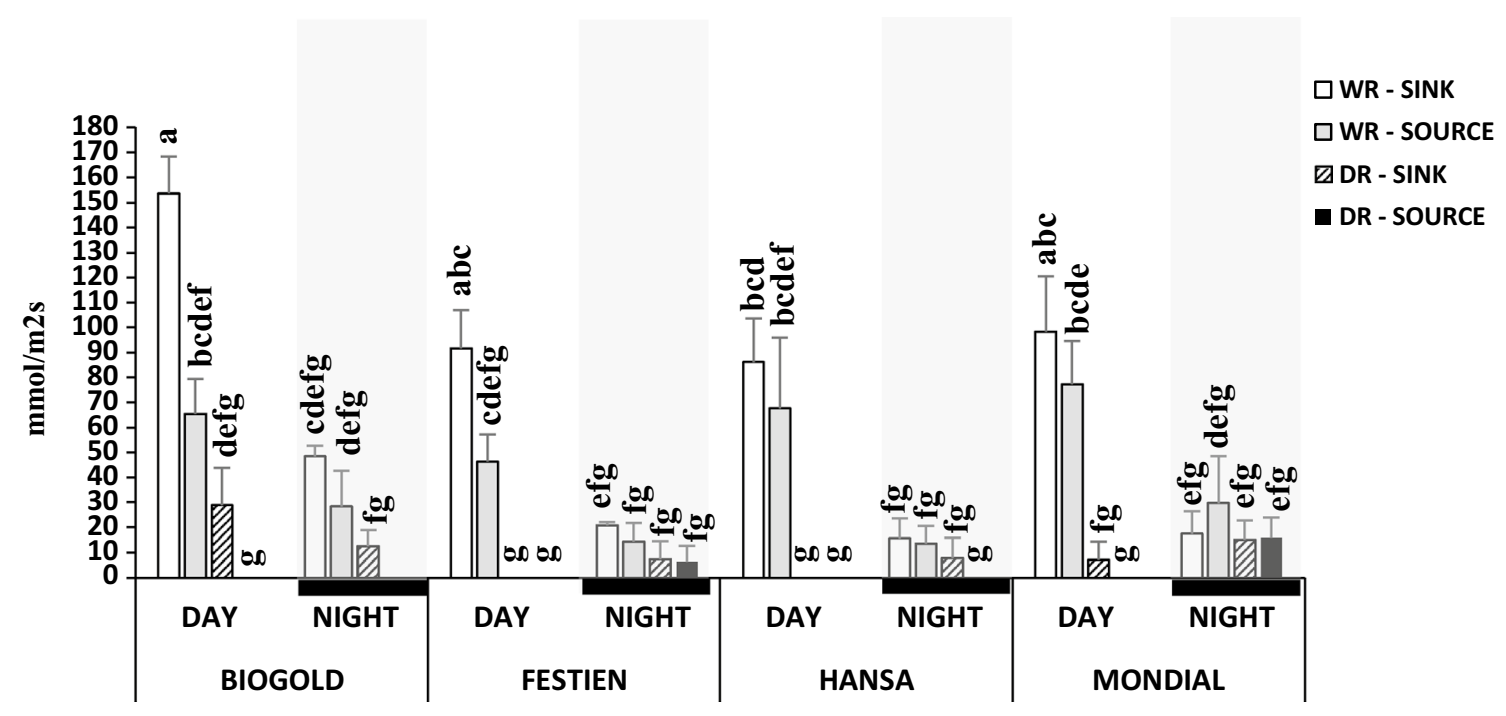

Fig. 2 Stomatal conductance in source and sink leaves of four cultivars after 21 days of dehydration (DR) and normal watering (WR), during the day (09:30-11:00 h) and at night (19:00-21:00 h). Letters $(\mathrm{a}-\mathrm{g})$ are used to indicate significant differences at $p$ value $(\alpha=0.05)$.
Error bars $=$ standard deviation between three biological replicates. Light period: artificial lighting (02:00)—Dawn (08:00)—Dusk (18:00) 


\section{Xylem and phloem flow}

The MRI results showed that under both control and dehydrated conditions, the plants exhibited a typical diurnal xylem flow pattern, with highest values of all xylem flow characteristics (i.e., xylem volume flow, xylem average velocity, and xylem flow conducting area) during the day and the lowest at night (Fig. 3). We could detect these xylem fluxes, because the plants received milder stress treatment in the MRI than in the greenhouse where stomatal conductance was hardly observed. The night values of xylem flow characteristics in the MRI were much lower under stress than in control conditions (Fig. 3). The peaks of xylem volume flow, xylem average velocity, and xylem flow conducting area were much lower in the dehydrated Mondial plant than in the water-limited Biogold plant (Fig. 3).

Phloem flow characteristics did not show a significant difference between day and night, especially under stress (Fig. 4). In control conditions, there was a day-night pattern, but the flow was generally low (Fig. 4). Phloem volume flow was about 100- and 1000-fold less than xylem volume flow in Biogold and Mondial, respectively, under stress and control conditions.

\section{Xylem cross section}

Three transverse sections of upper and lower stem regions of Biogold and Mondial were sampled from three plants (replicates) per genotype to investigate the effect of dehydration

(a)

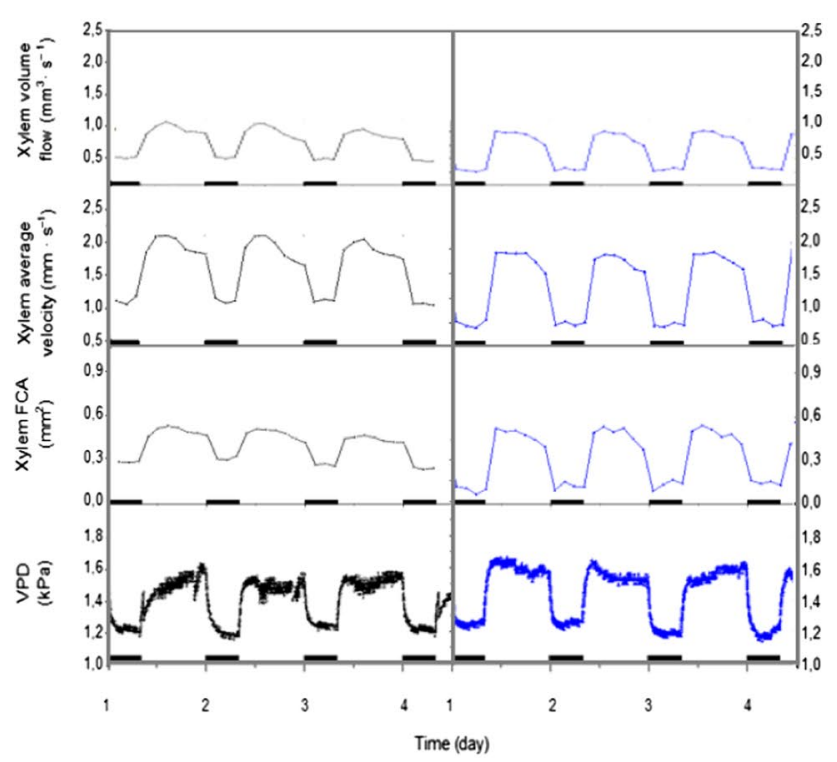

Fig. 3 MRI measurements of xylem flow characteristics in the lower stem of a Biogold and $\mathbf{b}$ Mondial, under control and dehydrated conditions showing xylem volume flow, xylem average flow veloc- on the morphology of transport vessels. A microscopic view of the stem cross-section at 28 days after stress application revealed that the xylem ring in the lower stem of Biogold occupied a significantly larger surface area than in the upper stem under both stress and control conditions (Fig. 5). In Mondial, xylem ring occupied a similar surface area in both upper and lower stem (Fig. 5). There was no significant reduction in the total number of xylem vessels under stress in the upper and lower stem of both cultivars (Fig. 6a), but total area of xylem vessels was less under stress, and less in upper stem than lower stem (Fig. 6b), although this xylem vessel area reduction under stress was only significant in the lower stem of Biogold $(p \leq 0.05)$. There was an increase in xylem density per unit area under dehydration in lower stem but not in the upper stem (Fig. 6c). Also, the increase in xylem density in lower stem was significant in Biogold but not Mondial. The lower stem diameter of Mondial was significantly larger than the upper stem diameter, whereas in Biogold, both regions of stem were about the same diameter size (data not shown). By categorising xylem vessels into size classes, the xylem vessel size composition and dehydration effects on xylem vessel size were further investigated.

Intermediate-sized vessels $(20-60 \mu \mathrm{m})$ were the most abundant (Fig. 7a, b). The lower stem generally had more vessels of the large size range $(>80 \mu \mathrm{m})$ than the upper stem. There was a tendency to more small-sized vessels $(0-20 \mu \mathrm{m})$ under dehydration in both cultivars (Fig. 7a). In the lower stem, dehydration stress significantly reduced the number of vessels in size class $>60 \mu \mathrm{m}$ in Biogold. In

\section{(b)}

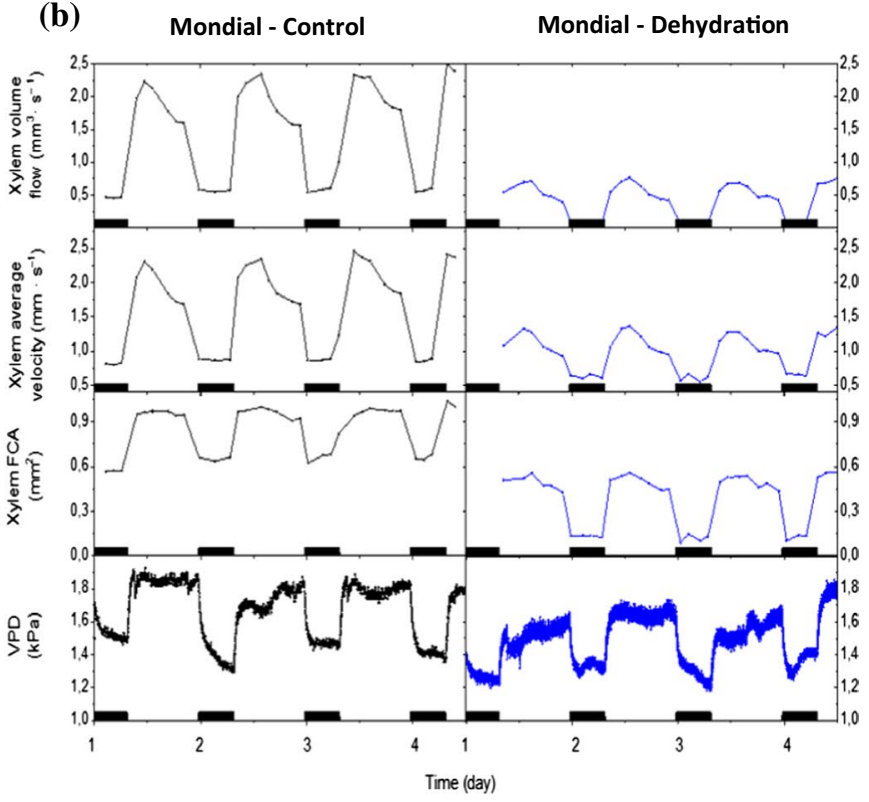

ity, xylem flow conducting area (FCA), and vapour pressure deficit (VPD), all as a function of time in days. Black rectangles represent night-time 


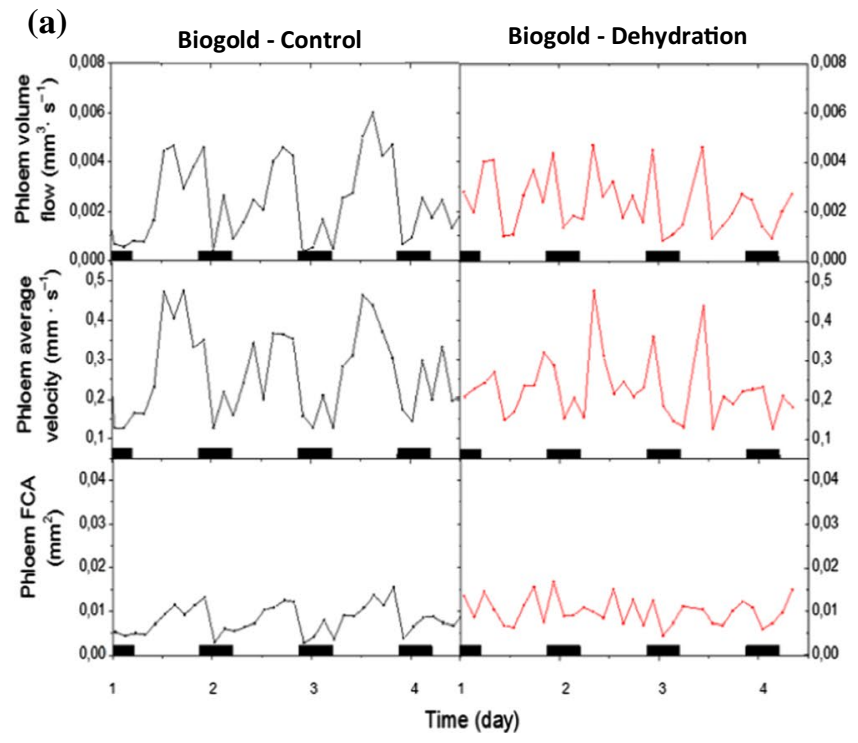

Fig. 4 MRI measurements of phloem flow characteristics in the lower stem of a Biogold and $\mathbf{b}$ Mondial, under control and dehydrated conditions showing phloem volume flow, phloem average flow velocity,



and phloem flow conducting area (FCA), all as a function of time in days. Black rectangles represent night-time

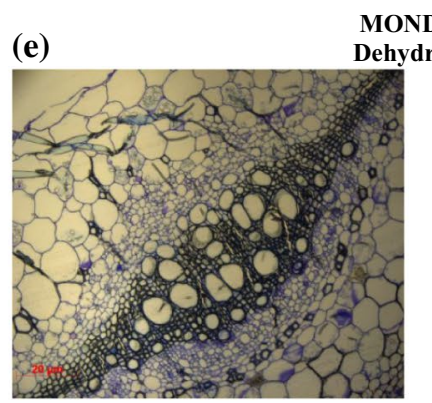

MONDIAL
Dehydration

(f)
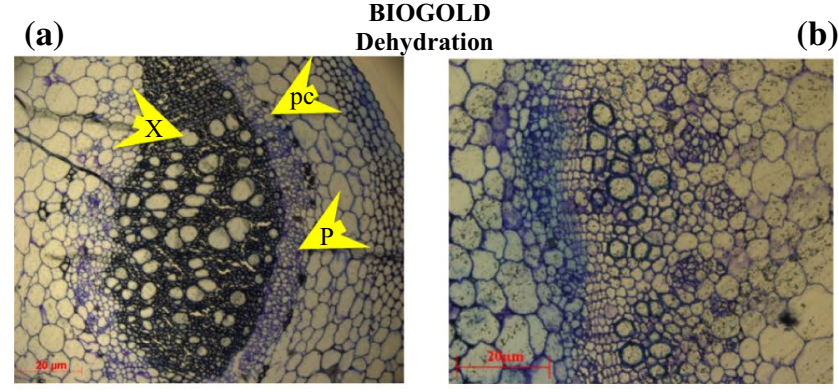

(c)
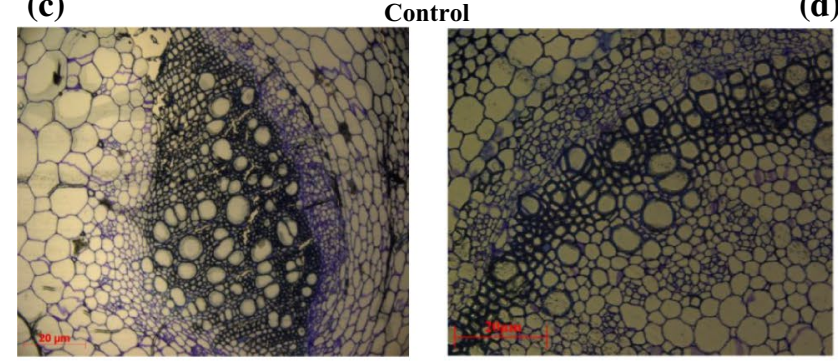

Fig. 5 Stem cross section images of Biogold and Mondial under control and dehydrated conditions at 28 days after stress application. For Biogold under dehydration stress, a lower stem and $\mathbf{b}$ upper stem; and under control treatment, $\mathbf{c}$ lower stem and $\mathbf{d}$ upper stem. For Mondial

Mondial, the reduction in number of vessels under stress was only significant in the $60-80 \mu \mathrm{m}$ size class (Fig. $7 \mathrm{~b}$ ). The intermediate-sized vessels $(20-60 \mu \mathrm{m})$ generally contributed most to the conducting xylem area in the upper region of the stem (Fig. 7c). Also, the effect of dehydration on xylem vessel area was observed only on the



under stress, e lower stem and f upper stem; and under control treatment, $\mathbf{g}$ lower stem and $\mathbf{h}$ upper stem. Yellow arrowheads have been used to indicate xylem vessel $(\mathrm{X})$, phloem $(\mathrm{P})$, and pericycle $(\mathrm{pc})$ in the first plate. Bar always represents $20 \mu \mathrm{m}$

intermediate-sized vessels (Fig. 7c). However, for the lower stem region, the bigger sized vessels $(>60 \mu \mathrm{m})$ were significantly reduced under stress, and intermediate-sized classes contributed more to the conducting xylem area (Fig. 7d). Reduction in xylem vessel area of lower stem (Fig. 6b) basically affected larger sized vessels (Fig. 7d). 
(a)

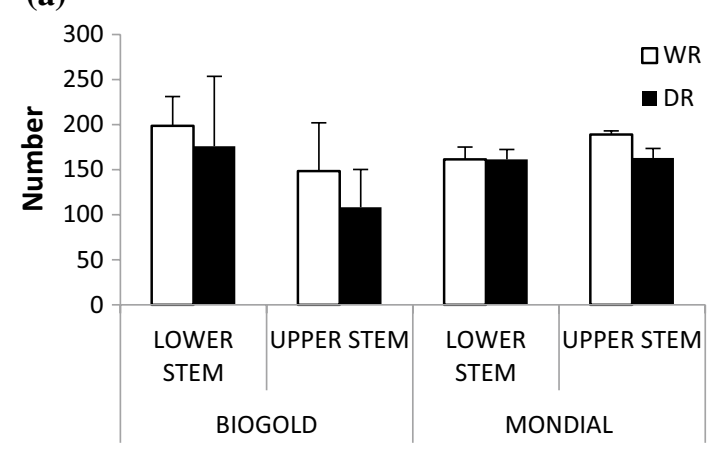

(b)

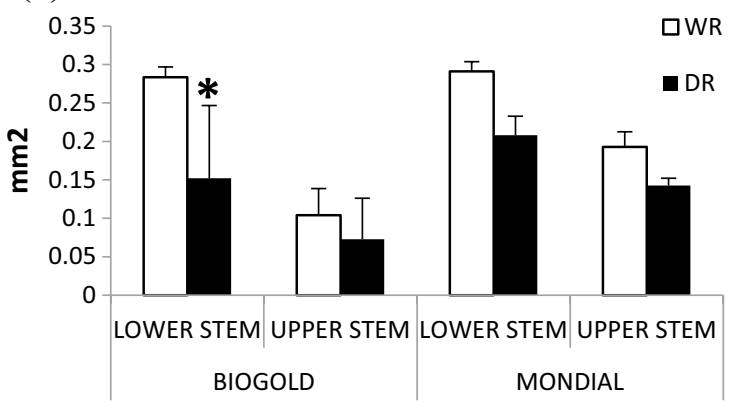

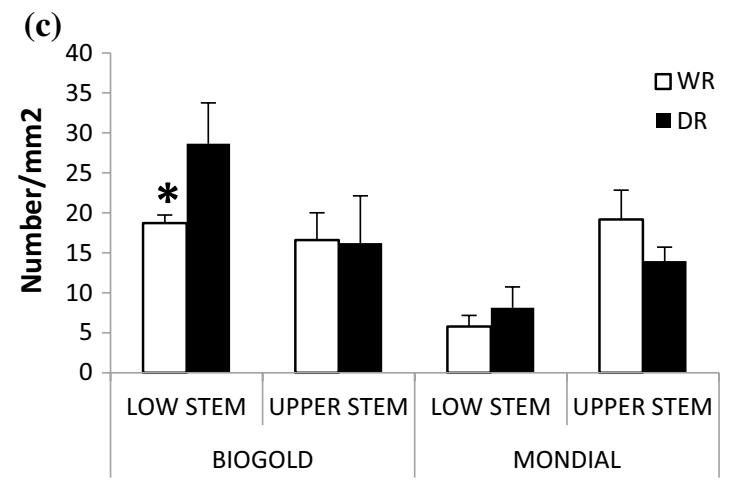

Fig. 6 Graphs showing a mean total number of xylem vessels, b mean total area of xylem vessels, and $\mathbf{c}$ density of xylem vessels per unit area of stem cross section, in upper and lower stem regions of
Biogold and Mondial. Error bars are standard deviations between three biological replicates. $*=$ sig. $(p \leq 0.05)$

in glucose content of sap only in Mondial, in the lower stem at night (Fig. 8c), and in Biogold, the upper stem at night (Fig. 8a). The fructose content of the sap in upper stem was not affected by stress treatment, day-/night-time points, or genotypic differences. However, in the lower stem under dehydration, fructose content showed an upward trend in Mondial at night and a downward trend in Biogold in day time (Fig. 8c, d). In summary, Biogold sugar content was less affected by the stress and less variable from day to night than that of Mondial.

\section{Discussion and conclusions}

Drought conditions interfere with stem structure and availability of transport materials (Banik et al. 2016; Zheng et al. 2009). Our findings from a multidisciplinary approach combining physiological, biochemical, microscopic and MRI methodologies, suggest that adaptations of the potato plant transport system to dehydration conditions may improve drought tolerance. 

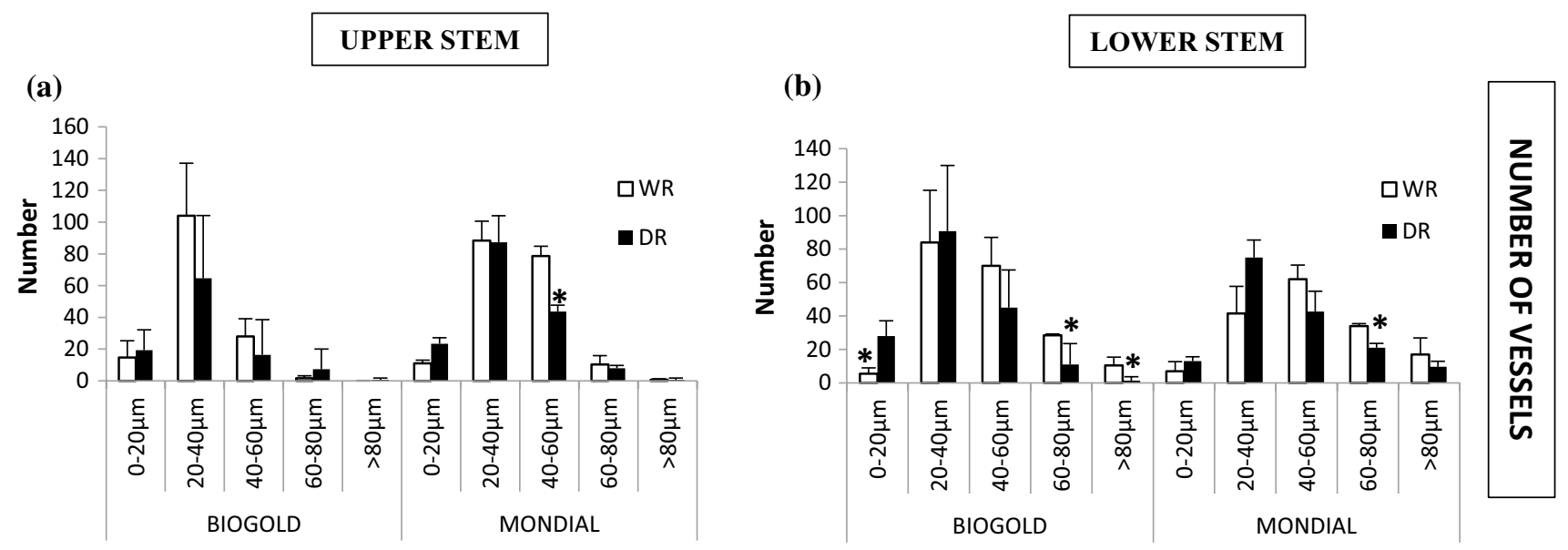

(c)

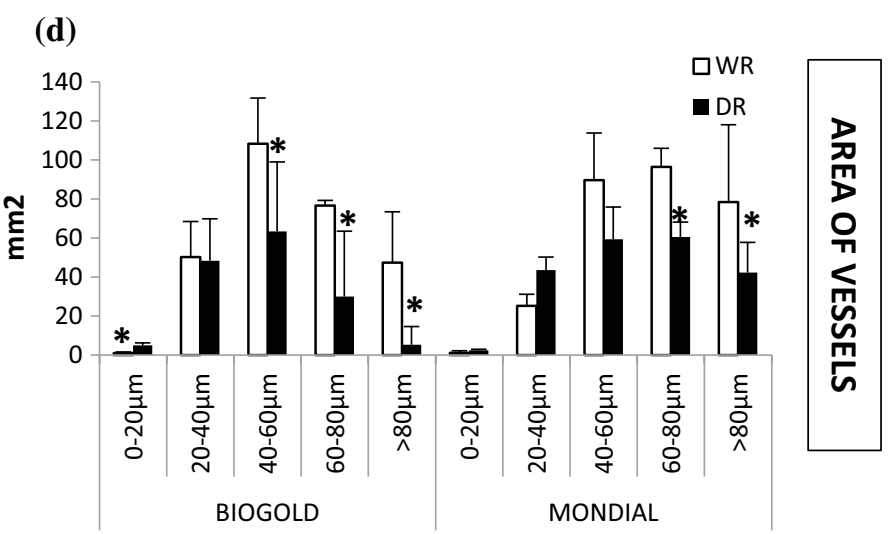

Fig. 7 Graphs showing the number of xylem vessels per size class in a upper stem and $\mathbf{b}$ lower stem; and area of xylem vessels per size class in $\mathbf{c}$ upper and $\mathbf{d}$ lower stem regions. Error bars are standard deviations between three biological replicates. ${ }^{*}=$ sig. $(p \leq 0.05)$

\section{Potato plant growth adaptations}

Reduction in plant growth after a period of drought stress is often seen as a negative symptom of stress (Albiski et al. 2012; Luitel et al. 2015), because the limited proliferation of new leaves associated with reduced stem elongation would infringe on the photosynthetic capacity of the plant (Farooq et al. 2009). However, our findings support the hypothesis that stem growth reduction during dehydration may also serve an advantageous purpose for the plants-to reduce transport distance (Koch et al. 2004). Hagen-Poiseuille's equation shows that when the variables of the equation are kept constant, an increase in tube length causes a reduction in flow rate of liquid through the tube (Niklas 2007). This suggests that stem growth reduction under limited water availability can facilitate an efficient water and nutrient transport in plants. Plant height is regulated by many factors including hormonal signals, physiological changes, and physical properties of the plant (Guerriero et al. 2014; Ljung 2013). Apparently, the stress effect on sugars impacts these various growth-regulatory factors, which stalls plant growth (Lastdrager et al. 2014; Koroleva et al. 2002). In our study, such a reduction in exponential growth of the plants during dehydration (Fig. 1a) may have aided the distribution of water, nutrients, and assimilates.

\section{Stomatal regulation of leaf transpiration and photosynthesis}

Stomatal opening/closure has implications for $\mathrm{CO}_{2}$ exchange, transpiration pull, and assimilate transport in the plant (Schapendonk et al. 1989; Wheeler et al. 1999). The stomatal closure of source leaves under dehydration in our greenhouse study as was observed in Biogold and Hansa (Fig. 2) may imply that the sink leaves needed to adapt carbon fixation rate, as was shown in another study where younger leaves maintained their stomatal conductance and photosynthesis despite the decline of these attributes in older leaves (Vos and Oyarzun 1987). Adapted photosynthetic rate in sink leaves under dehydration may not necessarily suffice for continuous growth, but at least it may meet the metabolic energy requirements of the sink leaves. In another study on 


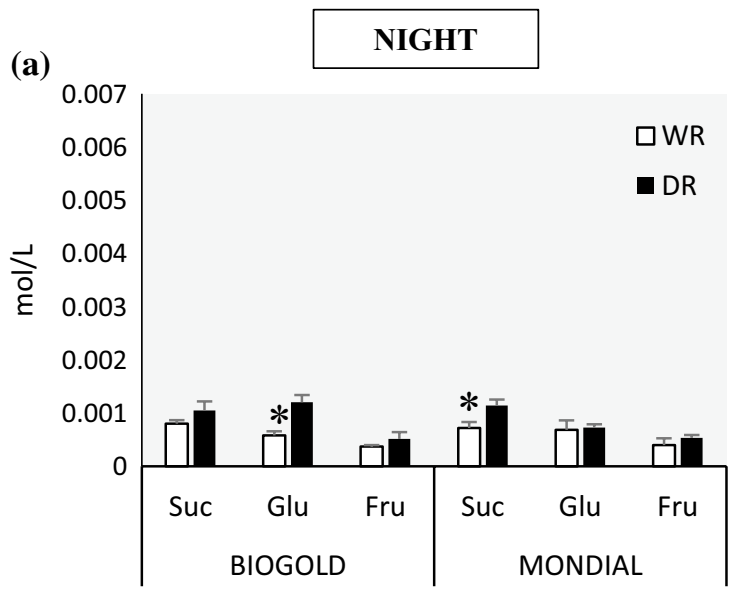

(c)

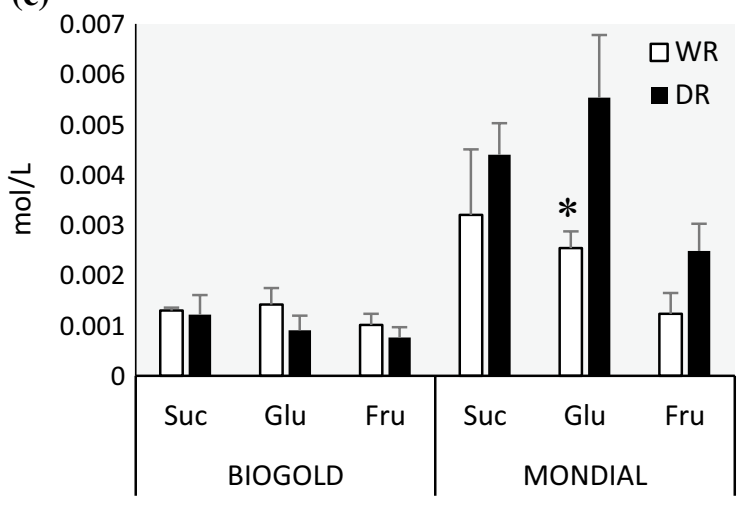

Fig. 8 Sugar content of the stem sap of Biogold and Mondial in a upper stem at night, $\mathbf{b}$ upper stem in day time, $\mathbf{c}$ lower stem at night, and $\mathbf{d}$ lower stem in day time. Error bars are standard deviations. Sig-

potato cv. Bintje in a growth chamber, photosynthesis in young leaves at different $\mathrm{CO}_{2}$ levels increased or decreased with respective increase or decrease in $\mathrm{CO}_{2}$ more strongly than in older leaves (Katny et al. 2005). In such instances of limited or adapted photosynthesis leading to less sugar availability in the plant (Iwona et al. 2012), and depending on the severity and duration of the stress, the source leaves in our study may have used up or transported the sugars which they already photosynthesized prior to complete stomatal closure. The impact of dehydration, which seems to be more severe on the source leaves than sink leaves, based on differences in stomatal closure (Fig. 2), may also lead to senescence and eventual leaf fall (Haverkort and Goudriaan 1994).

Surprisingly, the source and sink leaves of Festien and Hansa were closed under dehydration during the day when photosynthesis should take place and open at night when they should minimize water loss (Fig. 2). This complete stomatal closure especially of the sink leaf in day time was unexpected considering the young age of the leaves (Vos and Oyarzun 1987). Indeed, given the observed assimilate

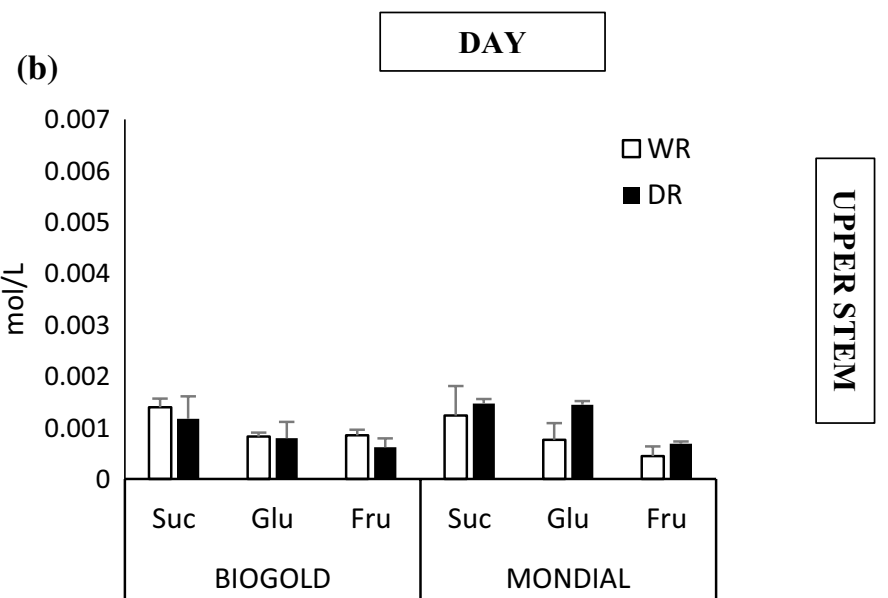

(d)



nificance of dehydration stress and genotype effects is given differently for each sugar. For each sugar, asterisks show levels of significant difference

production and partitioning in these cultivars (Fig. 1b), it is counterintuitive for the plants to completely shut off carbon assimilation. Moreover, there is no report of potato plants transiting from $\mathrm{C} 3$ to $\mathrm{C} 4$ or CAM metabolism under stress, and we do not have any evidence from our results to suppose such. Probably, a technical limitation of the Decagon SC-1 Leaf Porometer with which stomatal conductance was measured may explain this discrepancy. According to the manufacturer's specification, the porometer accuracy is $10 \%$ when stomatal conductance levels tend towards the extremes of zero and $1000 \mathrm{mmol}^{-1} \mathrm{~m}^{2} \mathrm{~s}^{-1}$ (https://www. decagon.com). This would mean that the conductance levels of these cultivars in the greenhouse must have been too low to be accurately detected by the porometer, and so the measurements tended to zero. However, the milder dehydration in the MRI measurement of Biogold and Mondial aided a clearer assignment of xylem flux as an indication of both transpiration and conductance under this mild stress with the expected day/night rhythm (Fig. 3). The adaptation of the plants' xylem flow to the severity of the drought conditions 
also affects the transport of photo-assimilates through the stem (Windt et al., 2006). Therefore, we observed some associations between the xylem and phloem flow patterns, although the associations were weaker under dehydration (Figs. 3, 4). However, there is evidence from another study on a 3-month-old tomato plant, that a mild dehydration during the MRI measurements caused a decrease in xylem volume flow as well as phloem volume flow, although the phloem flow velocity remained within defined boundaries (Prusova 2016). In our study, the phloem flow velocity of cv. Mondial was constantly in lower boundaries under both dehydration and control treatments than Biogold (Fig. 4), but the severely reduced xylem volume flow of cv. Mondial under stress given the VPD ranges in both treatments (Fig. 3) may be an indication of a dehydration sensitivity that could be associated with reduced water transport.

The reason for maintenance of stomatal conductance in the night as observed in the sink leaves of all cultivars (Fig. 2) remains unclear, especially under dehydration. It is known in many plant species that stomata are not completely closed at night (Caird et al. 2007) (Fig. 2). Advantages of stomatal opening at night when no photosynthesis occurs may include sustained nutrient transport (Snyder et al. 2003) and a compensation for phloem flow as inferred from phloem-to-xylem flux ratio, that is, Munch's counter flow (Windt et al. 2006). In fact, Windt et al. (2006) reported a low phloem-to-xylem flux ratio at night in tomato, indicating that the xylem flow was high in tomato at night in that study. However, this xylem night flux may be counteractive to water use efficiency according to a report in grape vine where genetic association was found between reduced night transpiration rate and high biomass (Coupel-Ledru et al. 2016). Therefore, maintenance of stomatal conductance at night under dehydration in our study (Fig. 2) may indicate a low water use efficiency of the potato plants. Additionally, it was demonstrated that stomatal response is reversed depending on a combination of different severities of dehydration and temperature fluctuations (Schulze et al. 1973). That is, stomatal opening under heat stress that coincides with low dehydration tends to revert to stomatal closure with increasing dehydration stress severity, suggesting a multifactorial effect. This may imply in our study that multifactorial effects with temperature transitions from day to night may have played a role, or some other unforeseen pleotropic effects. Therefore, better controlled conditions are highly recommended for investigating the effects of more severe dehydration stress, or a more sensitive detection system like LICOR may be used.

\section{Adaptation of transport vessel size}

Water and assimilate flow rates are partly influenced by the properties of the transport conduits (Kim et al. 2014;
Thompson and Holbrook 2003). In our study, the stem cross sections revealed some genotype-specific features like the increased xylem vessel density per stem area by the abundance of small-sized vessel elements in Biogold that could potentially aid water transport management under dehydration conditions (Fig. 6). The importance of the size of water transport conduits during water scarcity has been demonstrated in tree species that utilize tracheids as the preferred water transport channels, since their narrow diameter provides water transport with adaptation against cavitation and embolism (Sperry et al. 1994). We may speculate from our observation that the larger sized xylem rings relative to stem cross-sectional area in Biogold may suggest the presence of more tracheids in Biogold than in Mondial as unique genotypic features, but our measurements do not provide enough evidence to support or argue against this. A previous study on the potato plant morphology reported that tracheids and wood parenchyma are scattered amidst the larger xylem vessels (Artschwager 1918), suggesting that the potato plant xylem may consist of different tissue types for which its xylem area is generally larger than the tomato xylem area (Potter 1923). Moreover, there are no reports on the role of tracheids in preventing cavitation and embolism in crop species under dehydration stress. However, the increased smalldiameter vessels in Biogold under dehydration in our study (Fig. 6) probably enhanced the adhesion forces between water molecules and walls of the vessel elements (Fig. 3), which may aid in maintaining the water column as a means of reducing cavitation.

Furthermore, there is no indication from our observations that the reduction in the number of large-sized vessels in the lower stem (Fig. 7b) was due to lignification, even though in other plants, lignification of the vessels has been observed under stress scenarios, making the walls of the vessels thicker as a tolerance measure (Kim et al. 2008; SánchezAguayo et al. 2004; Gleason et al. 2016). Speculatively, tracheids if present may also contribute to such a mechanical reinforcement of the stem. This reduction in large-sized vessel area of the lower stem is a drought response mechanism that reduces the chances of drought-induced embolisms and cavitation that may impair transport through the vessels (Cochard and Tyree 1990; Lechthaler et al. 2016). Moreover, increasing the total xylem conducting area by increasing the number of small-sized xylem elements as observed in this study (Figs. 6, 7) may arguably be an effective adaptation to water scarcity, since larger surface area-to-volume ratio is essential in hydraulics (Zhang et al. 2016). Therefore, the increase in xylem density per unit stem area (Fig. 6) likely enhances water uptake from roots (Jacobsen et al. 2007). In summary, although Hagen-Poiseuille's equation which indicates that a wider tube transmits more fluid than a narrow tube is valid under normal water availability, in water limitation condition like our study, narrow vessel size offers 
a practical solution to the challenges of less water uptake and cavitation.

\section{Sugar transport through the stem}

We investigated the sugar content of the lower and upper stem to assess the impact of water transport limitation on sugar partitioning, especially given the limited sensitivity of the MRI phloem flow measurement (Fig. 4). There are divergent views that support or oppose the fact that sucrose is the only transport form of sugars in plants (van Bel and Hess 2008). In our study, we observed that sucrose and the hexoses were equally present in the sap, although our method of sap collection may not exclude the fact that some local hexoses that are not in the transport stream may have as well been sampled. Nonetheless, our observation probably suggests that the sugar composition of assimilates that can be transported in potato plant may be quite dynamic. In another study on Ricinus communis under anoxic conditions, the authors observed severe reduction in sugar transport (Peuke et al. 2015). We did not observe any significant decrease in sugar amounts at both upper and lower stem, possibly because our data gives an indication of both transported and local sugar concentration at the two stem regions. On the other hand, the reported differences in the amount of sucrose and hexoses detected in the transported fraction of plants may also be due to different factors including environmental conditions, time point in the day, plant developmental stage, and sensitivity of the detection protocol (Duarte-Delgado et al. 2015).

Also, the terminal sink destination of the transported sugars, or the presence/absence of a sink destination, may play a role in dehydration tolerance or sensitivity of the plant. Mondial may have prioritized the upper shoot terminal sink, as shown from the leaf dry weight measurements (Supplementary Fig. 1) and tuber/shoot weight ratio at two time points, while Biogold invested more in tubers (Fig. 1b). The direction of transport of the synthesized sugars may depend on the driver of the assimilate transport (Lemoine et al. 2013). Divergent views have been reported about the transport of assimilates as either sink strength-driven (Marcelis 1996; Wolswinkel 1984) or source-driven (Farrar 1993; Lemoine et al. 2013). Our findings suggest sink strength as the main transport driver in the two genotypes, Mondial and Biogold, as shown from their tuber-to-shoot ratio (Fig. 1b) and tuber number (Supplementary Fig. 1), with contrasting priorities for carbon partitioning suggesting a competition between tuber and above-ground tissues. The role of molecular determinants like invertases, sucrose synthases, and sucrose transporters in this sink competition may, however, not be ruled out (Herbers and Sonnewald 1998; Aliche et al. 2020). Taken together, under limited water availability in the xylem conduits, sink strength may influence the direction of assimilate transport.

Author contribution statement EBA, HVA, RGFV, and CGvdL conceived and designed research. HVA, RGFV, and CGvdL provided reagents and analytical tools. EBA, MRS, and MO conducted experiments in greenhouse and wet laboratory. APB and EG conducted MRI experiments and analyses. EBA and APB wrote the manuscript. All authors read and approved the manuscript.

Acknowledgements We thank Andre Maassen, Bertus van der Laan, Alex Super (in memoriam), Maarten Peters, Faline Plantenga, Abelenda Jose, and Irma Hoendervangers for the contribution of their experience and time to the greenhouse and laboratory experiments of this study.

Funding This research was funded by the TopSector (TKI Tuinbouw en Uitgangsmaterialen, number 262), Averis Seeds, C. Meijer, HZPC Holland B.V., KWS POTATO, and in part by the BioSolar Cells open innovation consortium, supported by the Dutch Ministry of Economic Affairs, Agriculture and Innovation.

\section{Compliance with ethical standards}

Conflicts of interest The authors declare that they have no conflict of interest.

Open Access This article is licensed under a Creative Commons Attribution 4.0 International License, which permits use, sharing, adaptation, distribution and reproduction in any medium or format, as long as you give appropriate credit to the original author(s) and the source, provide a link to the Creative Commons licence, and indicate if changes were made. The images or other third party material in this article are included in the article's Creative Commons licence, unless indicated otherwise in a credit line to the material. If material is not included in the article's Creative Commons licence and your intended use is not permitted by statutory regulation or exceeds the permitted use, you will need to obtain permission directly from the copyright holder. To view a copy of this licence, visit http://creativecommons.org/licenses/by/4.0/.

\section{References}

Albiski F, Najla S, Sanoubar R, Alkabani N, Murshed R (2012) In vitro screening of potato lines for drought tolerance. Physiol Mol Biol Plants 18(4):315-321. https://doi.org/10.1007/s12298-012-0127-5

Aliche EB, Theeuwen TPJM, Oortwijn M, Visser RGF, Linden CG (2020) Carbon partitioning mechanisms in POTATO under drought stress. Plant Physiol Biochem 146:211-219. https://doi. org/10.1016/j.plaphy.2019.11.019

Artschwager EF (1918) Anatomy of the Potato Plant, with special reference to the ontogeny of the vascular system. J Agric Res $14: 221-252$

Baker DA, Moorby J (1969) The transport of sugar, water, and ions into developing potato tubers. Ann Bot 33(4):729-741

Banik P, Zeng W, Tai H, Bizimungu B, Tanino K (2016) Effects of drought acclimation on drought stress resistance in potato 
(Solanum tuberosum L.) genotypes. Environ Exp Bot 126:76-89. https://doi.org/10.1016/j.envexpbot.2016.01.008

Bradshaw JE (2010) Root and tuber crops. Springer, New York

Caird MA, Richards JH, Donovan LA (2007) Nighttime stomatal conductance and transpiration in $\mathrm{C}(3)$ and $\mathrm{C}(4)$ plants. Plant Physiol 143(1):4-10. https://doi.org/10.1104/pp.106.092940

Cernusak LA, Arthur DJ, Pate JS, Farquhar GD (2003) Water relations link carbon and oxygen isotope discrimination to phloem sap sugar concentration in Eucalyptus globulus. Plant Physiol 131(4):1544-1554. https://doi.org/10.1104/pp.102.016303

Cochard H, Tyree MT (1990) Xylem dysfunction in Quercus: vessel sizes, tyloses, cavitation and seasonal changes in embolism. Tree Physiol 6(4):393-407

Coupel-Ledru A, Lebon E, Christophe A, Gallo A, Gago P, Pantin F, Doligez A, Simonneau T (2016) Reduced nighttime transpiration is a relevant breeding target for high water-use efficiency in grapevine. Proc Natl Acad Sci USA 113(32):8963-8968. https:// doi.org/10.1073/pnas.1600826113

De Schepper V, De Swaef T, Bauweraerts I, Steppe K (2013) Phloem transport: a review of mechanisms and controls. J Exp Bot 64(16):4839-4850. https://doi.org/10.1093/jxb/ert302

Duarte-Delgado D, Narváez-Cuenca CE, Restrepo-Sánchez LP, Kushalappa A, Mosquera-Vásquez T (2015) Development and validation of a liquid chromatographic method to quantify sucrose, glucose, and fructose in tubers of Solanum tuberosum Group Phureja. J Chromatogr B 975:18-23. https://doi. org/10.1016/j.jchromb.2014.10.039

Farooq M, Wahid A, Kobayashi N, Fujita D, Basra SMA (2009) Plant drought stress: effects, mechanisms and management. Agron Sustain Dev 29(1):185-212. https://doi.org/10.1051/ agro:2008021

Farrar JF (1993) Sink strength: what is it and how do we measure it? A summary. Plant Cell Environ 16(9):1045-1046. https://doi. org/10.1111/j.1365-3040.1996.tb02061.x

Gartner BL (1995) Plant stems: physiology and functional morphology. Academic, San Diego

Gleason SM, Westoby M, Jansen S, Choat B, Hacke UG, Pratt RB, Bhaskar R, Brodribb TJ, Bucci SJ, Cao KF, Cochard H, Delzon S, Domec JC, Fan ZX, Feild TS, Jacobsen AL, Johnson DM, Lens F, Maherali H, Martínez-Vilalta J, Mayr S, McCulloh KA, Mencuccini M, Mitchell PJ, Morris H, Nardini A, Pittermann J, Plavcová L, Schreiber SG, Sperry JS, Wright IJ, Zanne AE (2016) Weak tradeoff between xylem safety and xylem-specific hydraulic efficiency across the world's woody plant species. New Phytol 209(1):123-136. https://doi.org/10.1111/nph.13646

Grayson M (2013) Agriculture and drought. Nature 501(7468):S1. https ://doi.org/10.1038/501S1a

Guerriero G, Hausman JF, Cai G (2014) No stress! Relax! Mechanisms governing growth and shape in plant cells. Int J Mol Sci 15:5094-5114

Haverkort AJ, de Ruijter FJ, van Evert FK, Conijn JG, Rutgers B (2013) Worldwide sustainability hotspots in potato cultivation. 1. Identification and mapping. Potato Res 56(4):343-353. https://doi. org/10.1007/s11540-013-9247-8

Haverkort AJ, Goudriaan J (1994) Perspectives of improved tolerance of drought in crops. Aspects Appl Biol 38:79-92

Herbers K, Sonnewald U (1998) Molecular determinants of sink strength. Curr Opin Plant Biol 1(3):207-216

Hijaz F, Killiny N (2014) Collection and chemical composition of phloem sap from Citrus sinensis L. Osbeck (Sweet Orange). PLoS ONE. https://doi.org/10.1371/journal.pone.0101830

Hijmans RJ (2003) The effect of climate change on global potato production. Am J Potato Res 80:271-279

Holbrook NM, Zwieniecki MA (2011) Vascular transport in plants. Academic, Cambridge
Homan NM, Windt CW, Vergeldt FJ, Gerkema E, Van As H (2007) 07 and 3 T MRI and sap flow in intact trees: xylem and phloem in action. Appl Magn Reson 32(1):157-170. https://doi.org/10.1007/ s00723-007-0014-3

Iwona M, Sławomir B, Magda F, Lech R (Eds.) (2012) Plant responses to sugar starvation, carbohydrates - comprehensive studies on glycobiology and glycotechnology, Chuan-Fa Chang. IntechOpen, London. 10.5772/51569

Jacobsen AL, Agenbag L, Esler KJ, Pratt RB, Ewers FW, Davis SD (2007) Xylem density, biomechanics and anatomical traits correlate with water stress in 17 evergreen shrub species of the Mediterranean-type climate region of South Africa. J Ecol 95(1):171183. https://doi.org/10.1111/j.1365-2745.2006.01186.x

Jensen K, Mullendore D, Holbrook NM, Bohr T, Knoblauch M, Bruus H (2012) Modeling the hydrodynamics of phloem sieve plates. Front Plant Sci. https://doi.org/10.3389/fpls.2012.00151

Johnson RW, Dixon MA, Lee DR (1992) Water relations of the tomato during fruit growth. Plant Cell Environ 15(8):947-953. https://doi. org/10.1111/j.1365-3040.1992.tb01027.x

Karley AJ, Douglas AE, Parker WE (2002) Amino acid composition and nutritional quality of potato leaf phloem sap for aphids. J Exp Biol 205(19):3009-3018

Katny MA, Hoffmann-Thoma G, Schrier AA, Fangmeier A, Jager HJ, van Bel AJ (2005) Increase of photosynthesis and starch in potato under elevated $\mathrm{CO}_{2}$ is dependent on leaf age. J Plant Physiol 162(4):429-438. https://doi.org/10.1016/j.jplph.2004.07.005

Kim HK, Park J, Hwang I (2014) Investigating water transport through the xylem network in vascular plants. J Exp Bot 65(7):1895-1904

Kim YH, Kim CY, Song WK, Park DS, Kwon SY, Lee HS, Bang JW, Kwak SS (2008) Overexpression of sweet potato swpa4 peroxidase results in increased hydrogen peroxide production and enhances stress tolerance in tobacco. Planta 227(4):867-881. https ://doi.org/10.1007/s00425-007-0663-3

Kinkade KE (1987) Boehringer Mannheim Organization. Nat Biotechnol. https://doi.org/10.1038/nbt1287-1339b

Knoblauch M, Peters WS (2010) Munch, morphology, microfluidics-our structural problem with the phloem. Plant Cell Environ 33(9):1439-1452. https://doi.org/10.111 1/j.1365-3040.2010.02177.x

Koch GW, Sillett SC, Jennings GM, Davis SD (2004) The limits to tree height. Nature 428(6985):851-854. https://doi.org/10.1038/ nature 02417

Köcher P, Gebauer T, Horna V, Leuschner C (2009) Leaf water status and stem xylem flux in relation to soil drought in five temperate broad-leaved tree species with contrasting water use strategies. Ann For Sci 66(1):101-101. https://doi.org/10.1051/forest/20080 76

Kooman PL, Rabbinge R (1996) An analysis of the relation between dry matter allocation to the tuber and earliness of a potato crop. Ann Bot 77:235-242

Koroleva OA, Tomos DA, Farrar J (2002) Changes in osmotic and turgor pressure in response to sugar accumulation in barley source leaves. Planta 215:210-219. https://doi.org/10.1007/s0042 5-002-0744-2

Lampinen MJ, Noponen T (2003) Thermodynamic analysis of the interaction of the xylem water and phloem sugar solution and its significance for the cohesion theory. J Theor Biol 224(3):285-298. https://doi.org/10.1016/S0022-5193(03)00165-6

Lastdrager J, Hanson J, Smeekens S (2014) Sugar signals and the control of plant growth and development. J Exp Bot 65(3):799-807. https://doi.org/10.1093/jxb/ert474

Lechthaler S, Robert EMR, Tonne N, Prusova A, Gerkema E, Van As H, Koedam N, Windt CW (2016) Rhizophoraceae mangrove saplings use hypocotyl and leaf water storage capacity to cope with soil water salinity changes. Front Plant Sci. https://doi. org/10.3389/fpls.2016.00895 
Lemoine R, Camera SL, Atanassova R, Dédaldéchamp F, Allario T, Pourtau N, Bonnemain JL, Laloi M, Coutos-Thévenot P, Maurousset L, Faucher M, Girousse C, Lemonnier P, Parrilla J, Durand M (2013) Source-to-sink transport of sugar and regulation by environmental factors. Front Plant Sci. https://doi.org/10.3389/ fpls.2013.00272

Ljung K (2013) Auxin metabolism and homeostasis during plant development. Development 140(5):943-950. https://doi.org/10.1242/ dev.086363

Luitel BP, Khatri BB, Choudhary D, Paudel BP, Jung-Sook S, Hur O, Baek HJ, Cheol KH, Yul RK (2015) Growth and yield characters of potato genotypes grown in drought and irrigated conditions of Nepal. Int J Appl Sci Biotechnol 3(3):513-519. https://doi. org/10.3126/ijasbt.v3i3.13347

Marcelis L (1996) Sink strength as a determinant of dry matter partitioning in the whole plant. J Exp Bot 47:1281-1291

Munch E (1930) Die Stoffbewegungen in der Pflanze. Fischer, Jena

Niklas KJ (2007) Maximum plant height and the biophysical factors that limit it. Tree Physiol 27(3):433-440

Obidiegwu JE, Bryan GJ, Jones HG, Prashar A (2015) Coping with drought: stress and adaptive responses in potato and perspectives for improvement. Front Plant Sci. https://doi.org/10.3389/ fpls.2015.00542

Osakabe Y, Osakabe K, Shinozaki K, Tran LSP (2014) Response of plants to water stress. Front Plant Sci. https://doi.org/10.3389/ fpls.2014.00086

Peuke AD, Gessler A, Trumbore S, Windt CW, Homan N, Gerkema E, Van As H (2015) Phloem transport under anoxia. Plant Cell Environ 38:433-447. https://doi.org/10.1111/pce.12399

Pockman WT, Sperry JS (2000) Vulnerability to xylem cavitation and the distribution of sonoran desert vegetation. Am J Bot 87(9):1287-1299

Potter D (1923) Morphological and physiological correlations in the solanaceae. Dissertation, University of Massachusetts Amherst

Prusova A (2016) Light on phloem transport (an MRI approach). Dissertation, Wageningen University and Research

Rueden CT, Schindelin J, Hiner MC, DeZonia BE, Walter AE, Arena ET, Eliceiri KW (2017) Image J2: ImageJ for the next generation of scientific image data. BMC Bioinform 18(1):529. https://doi. org/10.1186/s12859-017-1934-Z

Ryan MG, Asao S (2014) Phloem transport in trees. Tree Physiol 34(1):1-4. https://doi.org/10.1093/treephys/tpt123

Sánchez-Aguayo I, Rodríguez-Galán JM, García R, Torreblanca J, Pardo JM (2004) Salt stress enhances xylem development and expression of S-adenosyl-1-methionine synthase in lignifying tissues of tomato plants. Planta 220(2):278-285. https://doi. org/10.1007/s00425-004-1350-2

Schapendonk AHCM, Spitters CJT, Groot PJ (1989) Effects of water stress on photosynthesis and chlorophyll fluorescence of five potato cultivars. Potato Res 32(1):17-32. https://doi.org/10.1007/ bf02365814

Scheenen TW, van Dusschoten D, de Jager PA, Van As H (2000) Microscopic displacement imaging with pulsed field gradient turbo spin-echo NMR. J Magn Reson 142(2):207-215. https:// doi.org/10.1006/jmre.1999.1916

Schulze ED, Lange OL, Kappen L, Buschbom U, Evenari M (1973) Stomatal responses to changes in temperature at increasing water stress. Planta 110:29-42. https://doi.org/10.1007/BF00386920

Sellier D, Mammeri Y (2019) Diurnal dynamics of phloem loading: theoretical consequences for transport efficiency and flow characteristics. Tree Physiol 39:300-311. https://doi.org/10.1093/treep hys/tpz001

Sevanto S (2014) Phloem transport and drought. J Exp Bot 65(7):17511759. https://doi.org/10.1093/jxb/ert467

Sevanto S, Hölttä T, Holbrook NM (2011) Effects of the hydraulic coupling between xylem and phloem on diurnal phloem diameter variation. Plant Cell Environ 34(4):690-703. https://doi.org/10.1 111/j.1365-3040.2011.02275.x

Sheikholeslam SN, Currier HB (1977) Effect of water stress on turgor differences and 14C-assimilate movement in phloem of Ecballium elaterium. Plant Physiol 59(3):381-383. https://doi. org/10.2307/4264742

Snyde KA, Richards JH, Donovan LA (2003) Night-time conductance in $\mathrm{C} 3$ and $\mathrm{C} 4$ species: do plants lose water at night? J Exp Bot 54(383):861-865. https://doi.org/10.1093/jxb/erg082

Sperry JS, Nichols KL, June EMS, Eastlack SE (1994) Xylem embolism in ring- porous, diffuse-porous, and coniferous trees of northern Utah and interior Alaska. Ecology 75(6):1736-1752. https:// doi.org/10.2307/1939633

Thompson MV, Holbrook NM (2003) Scaling phloem transport: water potential equilibrium and osmoregulatory flow. Plant Cell Environ 26(9):1561-1577. https://doi.org/10.104 6/j.1365-3040.2003.01080.x

Torres-Ruiz JM, Diaz-Espejo A, Chamorro V, Fernández JE, Sebastiani L, Minnocci A, Infante JM (2011) Influence of the water treatment on the xylem anatomy and functionality of current year shoots of olive trees. Acta Hortic 922:203-208. https://doi.org/10.17660/ ActaHortic.2011.922.26

Tyree MT, Zimmermann MH (2013) Xylem structure and the ascent of sap. Springer, Berlin

Van As H (2006) Intact plant MRI for the study of cell water relations, membrane permeability, cell-to-cell and long distance water transport. J Exp Bot 58(4):743-756

Van Bel AJE (2003a) The phloem, a miracle of ingenuity. Plant, Cell Environ 26(1):125-149. https://doi.org/10.104 6/j.1365-3040.2003.00963.x

Van Bel AJE (2003b) Transport phloem: low profile. High Impact. Plant Physiology 131(4):1509-1510

Van Bel AJE, Hess PH (2008) Hexoses as phloem transport sugars: the end of a dogma? J Exp Bot 59(2):261-272. https://doi. org/10.1093/jxb/erm294

Vilagrosa A, Chirino E, Peguero-Pina JJ, Barigah TS, Cochard H, GilPelegrín E (2012) Xylem cavitation and embolism in plants living in water-limited ecosystems. In: Aroca R (ed) Plant responses to drought stress: from morphological to molecular features. Springer, Berlin, pp 63-109

Vos J, Oyarzun PJ (1987) Photosynthesis and stomatal conductance of potato leaves-effects of leaf age, irradiance, and leaf water potential. Photosynth Res 11(3):253-264. https://doi.org/10.1007/bf000 55065

West GB, Brown JH, Enquist BJ (1999) A general model for the structure and allometry of plant vascular systems. Nature 400:664-667. https://doi.org/10.1038/23251

Wheeler RM, Mackowiak CL, Yorio NC, Sager JC (1999) Effects of $\mathrm{CO} 2$ on stomatal conductance: do stomata open at very high $\mathrm{CO} 2$ concentrations? Ann Bot 83(3):243-251. https://doi.org/10.1006/ anbo.1998.0813

Windt CW, Vergeldt FJ, de Jager PA, Van As H (2006) MRI of longdistance water transport: a comparison of the phloem and xylem flow characteristics and dynamics in poplar, castor bean, tomato and tobacco. Plant Cell Environ 29(9):1715-1729. https://doi.org /10.1111/j.1365-3040.2006.01544.x

Wolswinkel P (1984) Phloem unloading and 'sink strength': the parallel between the site of attachment of Cuscuta and developing legume seeds. Plant Growth Regul 2(4):309-317. https://doi.org/10.1007/ bf00027290

Zhang YJ, Rockwell FE, Graham AC, Alexander T, Holbrook NM (2016) Reversible leaf xylem collapse: a potential, "circuit breaker" against cavitation. Plant Physiol 172(4):2261-2274. https ://doi.org/10.1104/pp.16.01191

Zheng X, Jitsuyama Y, Terauchi T, Iwama K (2009) Effects of drought and shading on non-structural carbohydrate stored in the stem of 
potato (Solanum tuberosum L.). Plant Prod Sci 12(4):449-452. https://doi.org/10.1626/pps.12.449

Zimmermann MR, Hafke JB, Van Bel AJ, Furch AC (2013) Interaction of xylem and phloem during exudation and wound occlusion in Cucurbita maxima. Plant Cell Environ 36:237-247. https://doi. org/10.1111/j.1365-3040.2012.02571.x

Zwieniecki MA, Melcher PJ, Feild TS, Holbrook NM (2004) A potential role for xylem-phloem interactions in the hydraulic architecture of trees: effects of phloem girdling on xylem hydraulic conductance. Tree Physiol 24(8):911-917. https://doi. org/10.1093/treephys/24.8.911

Publisher's Note Springer Nature remains neutral with regard to jurisdictional claims in published maps and institutional affiliations. 